\title{
CNTNAP2 wt Allele
}

National Cancer Institute

\section{Source}

National Cancer Institute. CNTNAP2 wt Allele. NCI Thesaurus. Code C73462.

Human CNT NAP2 wild-type allele is located within 7q35-q36 and is approximately 2305 $\mathrm{kb}$ in length. This allele, which encodes contactin associated protein-like 2 , may play a role in axonal organization. Mutations in this gene are associated with cortical dysplasia-focal epilepsy syndrome and may be involved in autism and the DFNB13 form of nonsyndromic deafness. 